\title{
A New Mutation $\left(\mathrm{db}^{3 \mathrm{~J}}\right)$ at the Diabetes Locus in Strain 129/J Mice
}

\author{
II. Studies of Pancreatic Alpha Cell Function in Culture \\ E. H. Leiter, I. Strack, and A. B. Eisenstein \\ The Jackson Laboratory, Bar Harbor, Maine, and Brooklyn Veterans Hospital, Brooklyn, New York, USA
}

Summary. Monolayer cell cultures from pancreatic islets of aging $129 / \mathrm{J}$ strain diabetes $\left(d b^{3 \mathrm{~J}} / d b^{3 \mathrm{~J}}\right)$ and lean littermate control mice were tested for differences in glucagon and insulin secretion in either serum-free Eagle's minimal essential medium (MEM) or Dulbecco's modified minimal essential medium (DMEM). There was a highly significant $(p<0.0001)$ main effect of genotype and type of culture medium on glucagon secretion with time. Thus, although numbers of A-cells were not demonstrably increased in $d b^{3 \mathrm{~J}} / d b^{3 \mathrm{~J}}$ cultures in DMEM, mean medium glucagon levels increased 2.7-, 18-, and 32-fold above littermate normal culture levels at days 4,6 , and 8 respectively. In MEM, the two populations could not be discriminated on the basis of glucagon secretion. By contrast, insulin secretion over culture days showed a highly significant $(\mathrm{p}<$ 0.0001 ) dependence on genotype, but not type of medium, with the B-cell enriched $d b^{3 \mathrm{~J}} / d b^{3 \mathrm{~J}}$ preparations secreting between 20 and 30 times as much insulin as controls in both media. Analysis revealed that the heightened secretory responsiveness of mutant A-cells in DMEM as compared to MEM was primarily elicited by the elevated DMEM amino acid concentration and specifically lysine $(0.8 \mathrm{mmol} / \mathrm{l}$ in DMEM versus $0.4 \mathrm{mmol} / 1$ in MEM). In pulse-chase experiments using 14 day $d b^{3 \mathrm{~J}} / \mathrm{d} b^{3 \mathrm{~J}}$ cultures, incorporation of ${ }^{3} \mathrm{H}$-tryptophan into protein that eluted from Biogel P-10 columns in the native glucagon peak indicates that DMEM stimulated glucagon biosynthesis as well as secretion. This study reveals an augmented sensitivity of $d b^{3 \mathrm{~J}} / d b^{3 \mathrm{~J}}$ A-cells to stimulation by basic amino acids in long-term culture.

Key words: Diabetes mice, pancreatic islets, cell culture, alpha cell, glucagon, beta cell, insulin, amino acids, serum-free media.
Studies on pre-diabetic $\mathrm{C} 57 \mathrm{BL} / \mathrm{KsJ}(\mathrm{BL} / \mathrm{Ks})$ and $\mathrm{C} 57 \mathrm{BL} / 6 \mathrm{~J}(\mathrm{BL} / 6)$ misty diabetic $(m d b / m d b)$ mice have shown hyperinsulinaemia as early as ten days postpartum, preceding both hyperphagia and hyperglycaemia [1]. When these studies were extended in vitro to pancreatic cell cultures from 4-7 day old animals, the B-cells did not exhibit abnormalities of insulin biosynthesis or secretion [2]. In contrast, cultured A-cells from the mutant pancreas exhibited levels of glucagon biosynthesis and release that were consistently elevated above those in littermate controls [2]. This early appearance of an A-cell secretory disturbance in short-term cell cultures is of interest because defective glucagon secretion is known to persist throughout adult life, even after $\mathrm{BL} / \mathrm{Ks}$ mutants make the transition from a hyperinsulinaemic to a relatively hypoinsulinaemic state $[3,4]$.

The role that A-cells play in the etiology and pathogenesis of the non-insulin dependent diabetes syndrome is unknown. While studies with the postnatal pancreas in vitro clearly suggested that $d b$ gene expression produced an intrinsic abnormality in Acell function, these studies were limited by the small numbers of mutant pups and islet cells available at a given age. Long-term studies were hindered by the fact that the cultures established from whole pancreatic digests were quite heterogenous. A rapidly dividing non-endocrine epithelioid celltype formed the bulk of the monolayer within $48 \mathrm{~h}$. Endocrine cells comprised less than $20 \%$ of the monolayer [2].

In the preceding paper [5], we have described the pancreatic morphology produced by the $d b^{3 \mathrm{~J}}$ mutation in strain $129 / \mathrm{J}$ albino mice. Extensive sustained islet (primarily B-) cell hyperplasia, accompanied in aging mutants by some atrophy and loss of exocrine cells, suggested to us that these mutants would be an excellent source of large quantities of islet cells for culture. Furthermore, physiological studies of these 

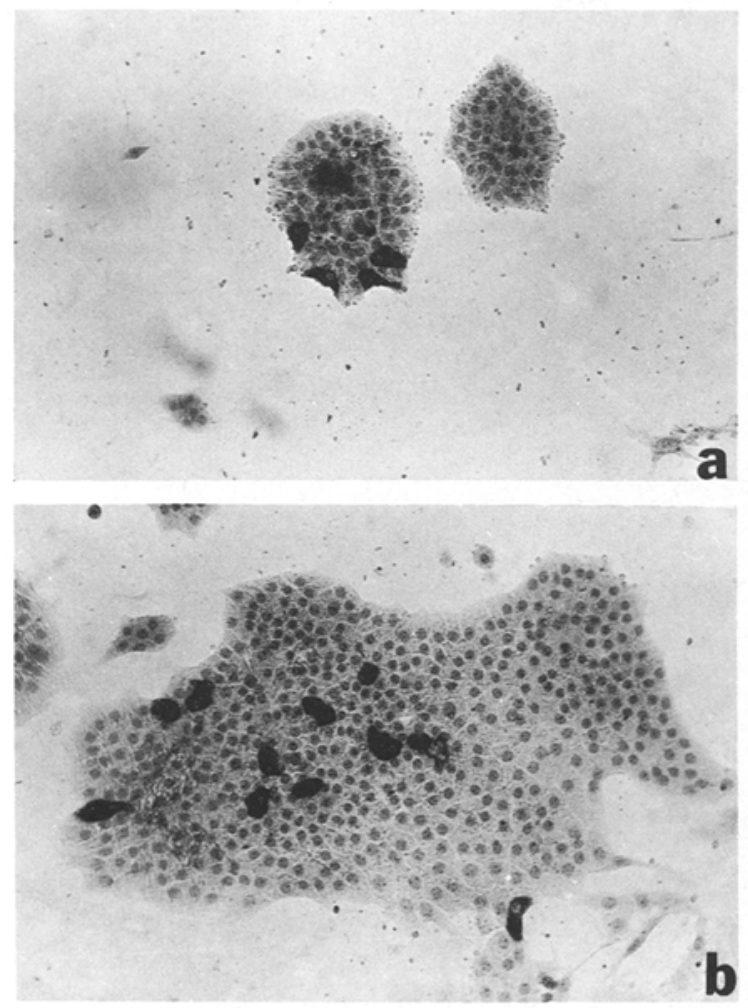

Fig. 1. Immunocytochemical peroxidase-antiperoxidase staining for glucagon in 14 day cultures of (a) $+/$ ? , (b) $d b^{3 \mathrm{~J}} / d b^{3 \mathrm{~J}}$ islet cells. Note that although islet cell monolayers are more expansive in $d b^{3 \mathrm{~J}}$ cultures, A-cell numbers are not markedly increased. $\times 210$

mutants suggested continued A-cell hyperfunction with aging, while function of the hyperplastic B-cell population seemed to return towards normal [5]. Thus, it appeared that islet cell cultures from 129/J diabetic mice would provide the opportunity to assess whether the apparent A-cell anomaly would persist in vitro.

\section{Materials and Methods}

Mice

Strain $129 / \mathrm{J} d b^{3 \mathrm{~J}} / d b^{3 \mathrm{~J}}$ and lean littermate $(+/$ ?) mice were maintained as described previously [5]. Animals were sacrificed between the ages of 6 and 13 months of age. Generally pancreases from one to two mutants and the same number of age-matched lean littermates were cultured in a single experiment.

\section{Cell Culture}

Culture methodology was as previously reported [6] with the modification that the collagenase concentration (type IV, Worthington Biochemicals, Freehold, N. J.) was reduced to $1 \mathrm{mg} / \mathrm{ml}$, using $4 \mathrm{ml}$ volumes (in Hanks' balanced salt solution) per pancreas. Procedures detailing purification of islet cells by decantation and discontinuous Ficoll-gradient centrifugation, followed by plating in mod- ified Eagle's minimal essential medium (MEM) containing $16.5 \mathrm{mmol} / \mathrm{l}$ glucose and Earle's salts, were as described before [6]. Culture media, media components, and dialyzed serum were obtained commercially (GIBCO, Grand Island, N. Y.). Dialyzed fetal calf serum (dFCS) was treated at $56^{\circ} \mathrm{C}$ for $30 \mathrm{~min}$ to inactivate complement $[7,8]$. Both MEM and Dulbecco's modified MEM (DMEM) were further supplemented with $15 \mathrm{mmol} / 1$ HEPES buffer, $0.2 \mathrm{mg} / \mathrm{ml}$ recrystallized bovine serum albumin (BSA, Sigma, St. Louis, Mo.), and antibiotics (penicillin, $100 \mathrm{units} / \mathrm{ml}$, and streptomycin, $100 \mu \mathrm{g} / \mathrm{ml}$ ). A $10 \%$ volume of $\mathrm{dFCS}$ was added only to the $16.5 \mathrm{mmol} / \mathrm{l}$ glucose-containing MEM medium used to initiate islet monolayers $(0-48 \mathrm{~h})$. Glucose concentrations and other alterations of the media, such as the addition of Eagle's non-essential amino acid (NEAA) mixture [9], are indicated in the text. Cultures were usually established in either $35 \mathrm{~mm}$ diameter Petri dishes (Lux, Newbury Park, Calif.) or in 8-chambered microculture chamber slides (Lab-Tek, Elkhart, Ind.). Analytical methods, including assays for immunoreactive glucagon and insulin were as described in the companion report [5].

\section{Glucagon Biosynthesis}

Glucagon biosynthesis was monitored by studying incorporation into cells of $\mathrm{L}-\left[5-{ }^{3} \mathrm{H}\right]$ trytophan, $20 \mathrm{Ci} / 1$ (Amersham, Arlington Hts., Ill.) at a concentration of $100 \mu \mathrm{Ci} / \mathrm{mmol}$ in tryptophan-free MEM or DMEM for the periods indicated in the text. Both BSA and antibiotics were omitted from the labelling media. Medium supernatants and cell extracts, as well as appropriate background controls, were processed as previously reported [2]. Alcohol was removed from acid ethanol extracts under a stream of air at room temperature, and labelled peptides were chromatographed through $1.5 \times 27 \mathrm{~cm}$ columns of Biogel P-10 equilibrated in $2 \mathrm{~mol} / \mathrm{l}$ propionic acid.

\section{Morphology}

Fixation of cultures for electron microscopy was as previously described [2]. The criteria for distinguishing various mouse islet cell types in culture on the basis of secretory granule ultrastructure have also been described earlier [6]. Peroxidase-anti-peroxidase (PAP) immunocytochemical staining for glucagon in cultured, Bouin's-fixed A-cells was identical to that described for paraffinembedded pancreatic sections [5]

\section{Statistical Analysis}

Hormone secretion data obtained from four separate experiments in which each treatment group comprised pairs of matched cultures of each genotype were submitted to statistical analysis in a balanced 2 (genotype) $\times 2$ (medium) $\times 4$ (day) analysis of variance (ANOVA). To improve homogeneity of variance, the raw data were transformed to logarithms before the analysis was conducted. Tests of simple, simple main effects were conducted as outlined by Winer [10] to determine significance of all possible genotype, medium, and culture day combinations. Significance was assumed at $\mathrm{p} \leqslant 0.05$.

\section{Results}

\section{Culture Morphology}

Removal of serum from cultures after $48 \mathrm{~h}$, followed by further maintenance in serum-free MEM, resulted in a loss of any non-endocrine epithelial cell types 


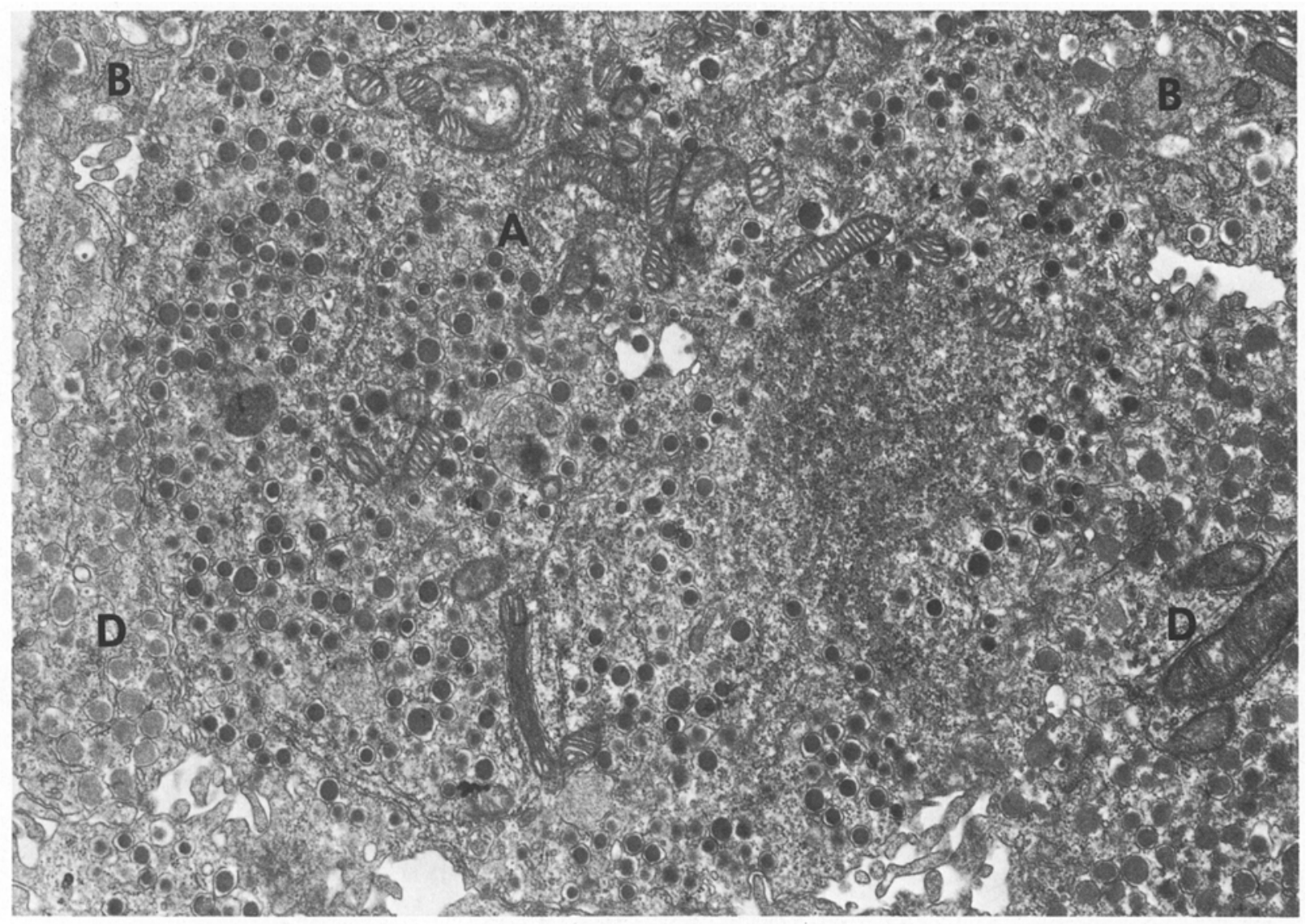

Fig. 2. Ultrastructure of a $d b^{3 \mathrm{~J}} / d b^{3 \mathrm{~J}}$ monolayer at day 8 in $5.5 \mathrm{mmol} / \mathrm{l}$ glucose-containing DMEM showing the presence of granulated A-, B-, and D-cells at the periphery of a monolayer. The A-cell is heavily-granulated in spite of evidence of glucagon hypersecretion into the culture medium. $\times 14,575$

(duct cells, exocrine cells) within 7 days. Fibroblastoid cells, sometimes present in small numbers at the outset of culture, did not proliferate under these conditions and cytolyzed between the first and second weeks. Clusters of islet cells, however, were conserved under these conditions, but endocrine populations from the mutant pancreas differed both qualitatively and quantitatively from cultures established from equal numbers of $+/$ ? pancreases. Mutant preparations were initially less heterogenous in composition, and unlike $+/ 2$ islet cells, which required $48 \mathrm{~h}$ to attach and up to a week to become well-flattened and spread in serum-free media, islet cells from mutant pancreas attached within $24 \mathrm{~h}$ and were generally well-flattened and were increasing in size by $72 \mathrm{~h}$. Whereas Ficoll purified $+/$ ? islet cells settled down as small sparse clusters ( 2 to 70 cells), the size of the more numerous $d b^{3 \mathrm{~J}} / d b^{3 \mathrm{~J}}$ islet cell aggregates was much larger so that on a per-pancreas basis, yields were increased at least 10-fold (Fig. 1a, 1b). While light and electron microscopic studies revealed occasional necrotic (usually B-) cells in both genotype cultures in MEM and DMEM, no qualitative differences could be detected over the first week of culture. By 14 days of culture, however, variable cytotoxicity and cell loss were evident in $+/$ ? cultures in both types of media, while the $d b^{3 \mathrm{~J}} / d b^{3 \mathrm{~J}}$ cultures remained largely intact and viable. No cell division occurred in either population under serum-free conditions.

Immunocytochemical staining with anti-glucagon antiserum did not reveal obvious differences in the numbers of mutant versus normal A-cells in cell clusters (Fig. 1a, 1b). Light and electron microscopic studies revealed that granulated B-cells predominated in both types of cultures (Fig. 2). Well granulated A-, D- (Fig. 2), and PP-cells (not shown) were also observed in both types of cultures. The greater mass of well-granulated B-cells in $d b^{3 \mathrm{~J}} / d b^{3 \mathrm{~J}}$ cultures (maintained in $5.5 \mathrm{mmol} / 1$ glucose-containing media just prior to fixation) was the major ultrastructural feature distinguishing them from normal cell cultures. Only B-cell granulation appeared to change in cultures with high media glucose concentrations that 
Table 1. Mean glucagon secretion (pg/48 $\mathrm{h} \pm \mathrm{SEM}$ ) by normal and diabetic $\left(d b^{3 \mathrm{~J}} / d b^{3 \mathrm{~J}}\right)$ mice islets in monolayer cultures. MEM, Eagle's minimal essential medium. DMEM, Dulbecco's MEM

\begin{tabular}{|c|c|c|c|c|c|c|c|c|c|c|c|}
\hline & $\frac{\text { MEM }}{\text { day } 2}$ & day 4 & day 6 & day 8 & $\begin{array}{l}\text { Day } \\
\text { effect }^{\text {a }}\end{array}$ & $\frac{\text { MEM }}{\text { day } 2}$ & $\frac{\text { DMEM }}{\text { day } 4}$ & day 6 & day 8 & $\begin{array}{l}\text { Day } \\
\text { effect }^{\mathrm{a}}\end{array}$ & $\begin{array}{l}\text { Medium } \\
\text { effect }^{\mathrm{b}}\end{array}$ \\
\hline$+/ ?$ & $\begin{array}{r}8114.0 \\
\pm 7.1\end{array}$ & $\begin{array}{r}211.0 \\
\pm 40.3\end{array}$ & $\begin{array}{r}162.5 \\
\pm 41.5\end{array}$ & $\begin{array}{r}124.8 \\
\pm 42.4\end{array}$ & $<0.05$ & $\begin{array}{r}128.8 \\
\pm 7.1\end{array}$ & $\begin{array}{r}548.5 \\
\pm 53.8\end{array}$ & $\begin{array}{r}189.0 \\
\pm 18.3\end{array}$ & $\begin{array}{r}105.8 \\
\pm 16.5\end{array}$ & $<0.005$ & $\begin{array}{l}<0.001 \text { for } \\
\text { day } 4\end{array}$ \\
\hline$d b^{3 \mathrm{~J}} / d b^{3 \mathbf{J}}$ & $\begin{array}{r}144.0 \\
\pm 29.7\end{array}$ & $\begin{array}{r}121.0 \\
\pm 31.1\end{array}$ & $\begin{array}{r}149.3 \\
\pm 32.8\end{array}$ & $\begin{array}{r}142.3 \\
\pm 41.5\end{array}$ & NS & $\begin{array}{r}91.5 \\
\pm 13.3\end{array}$ & $\begin{array}{r}1275.0 \\
\pm 200.1\end{array}$ & $\begin{array}{r}2130.0 \\
\pm 290.7\end{array}$ & $\begin{array}{r}2190.0 \\
\pm 712.3\end{array}$ & $<0.0001$ & $\begin{array}{l}<0.0001 \text { for } \\
\text { days } 4,6,8\end{array}$ \\
\hline $\begin{array}{l}\text { Genotype } \\
\text { effect }^{\mathrm{c}}\end{array}$ & NS & $<0.05$ & NS & NS & & NS & $<0.005$ & $<0.0001$ & $<0.0001$ & & \\
\hline
\end{tabular}

Data collected from 4 separate experiments

${ }^{a}$ p values of $F$ ratio obtained in test of simple, simple main effects of days

$\checkmark \mathrm{p}$ values of $F$ ratio obtained in test of simple, simple main effects of media

${ }^{c} \mathrm{p}$ values of $F$ ratio obtained in test of simple, simple main effects of genotype

Table 2. Mean insulin secretion (ng/48 $\mathrm{h} \pm \mathrm{SEM}$ ) by normal and diabetic ( $\left.d b^{3 \mathrm{~J}} / d b^{3 \mathrm{~J}}\right)$ mouse islets in monolayer cultures. MEM, Eagle's minimal essential medium. DMEM, Dulbecco's MEM

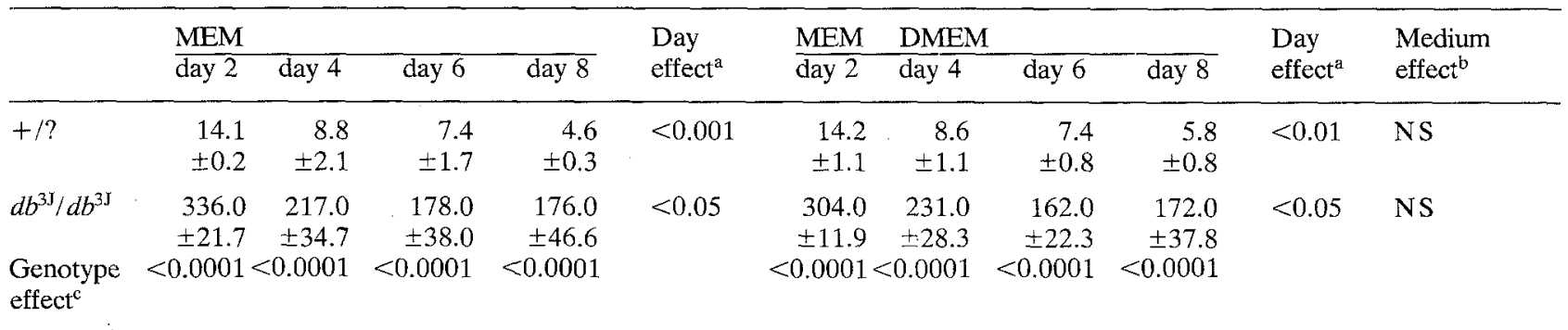

Data collected from same 4 replications shown in Table 1. Footnotes same as for Table 1

stimulated insulin secretion. A-cells did not undergo degranulation after growth in media that stimulated glucagon release.

\section{Hormone Secretion}

Data presented in Tables 1 and 2 contrast the altered behaviour of A-cells, but not B-cells, upon introduction of DMEM medium on the second culture day. There was no effect of genotype on medium glucagon levels found in serum-containing MEM at the initial day 2 sampling point (Table 1). Glucagon secreted by cultures into MEM medium showed a significant difference $(p<0.05)$ due to genotype only at day 4 where $+/$ ? cultures produced a slightly greater glucagon response than did $d b^{3 \mathrm{~J}} / d b^{3 \mathrm{~J}}$ cultures. In contrast, a highly significant $(\mathrm{p}<0.0001)$ genotype dependence for insulin levels was observed in this same medium over all days (Table 2).

The shift at $48 \mathrm{~h}$ into serum-free DMEM, but not MEM, produced a strong stimulation of glucagon in both mutant and $+/$ ? cultures (Table 1 ). For $+/$ ? cultures, the medium provided a significant difference in response only in the day 4 samples at which time the DMEM cultures were secreting over twice as much glucagon as the control cultures in MEM.
For $d b^{3 \mathrm{~J}} / d b^{3 \mathrm{~J}}$ cultures, the DMEM medium yielded a significantly higher mean glucagon release on all days after introduction (2.7-, 18-, and 32-fold elevations above respective $+/$ ? levels at day 4,6 , and 8 samplings). No similar genotype/medium interaction was observed in respect of insulin levels in the same media samples (Table 2). The very high insulin levels were predicated on the $d b^{3 \mathrm{~J}} / d b^{3 \mathrm{~J}}$ genotype independently of the medium.

In analyzing glucagon and insulin secretory response versus days of culture, a significant change was seen for all conditions except for glucagon secretion by $d b^{3 \mathrm{~J}} / d b^{3 \mathrm{~J}}$ cultures in MEM medium (Table 1 ). This glucagon response across days was far greater for $d b^{3 \mathrm{~J}} / d b^{3 \mathrm{~J}}$ than for $+/$ ? cultures in the DMEM medium. Mean insulin secretion by both genotype classes declined both in serum-free MEM and DMEM as compared to the initial (day 2) sample in serum-containing medium.

As shown in Table 3, DMEM differs from MEM in containing a modified salt solution and includes ferric nitrate, pyruvate, a four-fold increase in vitamin concentrations a 2 -fold increase in glutamine and many of the 13 amino acids contained in MEM. DMEM contains in addition serine and glycine, and when boosted with the non-essential amino acid 
Table 3. Comparison of selected MEM (Eagle's minimal essential medium) and DMEM (Dulbecco's MEM) constituents (mmol/l)

\begin{tabular}{lcc}
\hline Constituents & $\begin{array}{l}\text { MEM } \\
(30 \text { total })\end{array}$ & $\begin{array}{l}\text { DMEM } \\
(34 \text { total })\end{array}$ \\
\hline Inorganic salts & & \\
$\mathrm{CaCl}_{2}$ & 1.80 & 1.80 \\
$\mathrm{NaH}_{2} \mathrm{PO}_{4} \cdot \mathrm{H}_{2} \mathrm{O}$ & 1.01 & 0.91 \\
$\mathrm{NaHCO}_{3} \cdot 9 \mathrm{H}_{2} \mathrm{O}$ & 26.19 & 44.04 \\
$\mathrm{Fe}\left(\mathrm{NO}_{3}\right)_{3} \cdot 9 \mathrm{H}_{2}^{-3}$ & - & $0.25 \times 10^{-3}$ \\
Amino acids & & \\
L-Arginine & 0.60 & 0.40 \\
L-Lysine & 0.40 & 0.80 \\
L-Histidine & 0.20 & 0.20 \\
L-Tryptophan & 0.05 & 0.08 \\
L-Isoleucine & 0.04 & 0.08 \\
L-Leucine & 0.40 & 0.80 \\
L-Serine & - & 0.40 \\
L-Glycine & - & 0.40 \\
Vitamins & & \\
Thiamine $\cdot \mathrm{HCl}$ & 0.003 & 0.012 \\
I-Inositol & 0.01 & 0.04 \\
Nicotinamide & 0.008 & 0.03 \\
Other components & & \\
Glucose & 5.5 & 5.5 \\
Pyruvate & - & 1.0 \\
L-Glutamine & 2.0 & 4.0 \\
- & & \\
\hline
\end{tabular}

(NEAA) mixture, aspartic acid, glutamic acid, and asparagine.

To determine the mechanism by which DMEM stimulated cultured A-cells, MEM was modified to contain, in separate trials, DMEM levels of either [1] balanced salt solution, [2] amino acids, [3] vitamins, and [4] pyruvate and glutamine. Data presented in Figure 3 reveal that most of the DMEM-mediated stimulation could be attributed to the amino acid component insofar as MEM modified to contain DMEM concentrations of amino acids and salts (the latter alone did not alter glucagon release) produced a dramatic rise in glucagon but not insulin secretion. As in the previous statistical analysis of MEM versus DMEM treatment, a three way analysis of variance of the data in Figure 3 gave a significant genotype/ medium/days interaction when glucagon secretion in response to elevated amino acid concentration was considered (all $\mathrm{p}<0.05$ in modified MEM; all nonsignificant in MEM). Again, when insulin release was considered, a significant main effect of genotype only (all $p<0.0001$ ) and not of medium or culture days was noted. The increase with time of glucagon secretion in mutant cultures was accompanied by a 5 -fold elevation at day 8 in glucagon extracted from cell clusters by acid/ethanol (data not shown). Cellular insulin levels in these same cultures were not significantly altered.

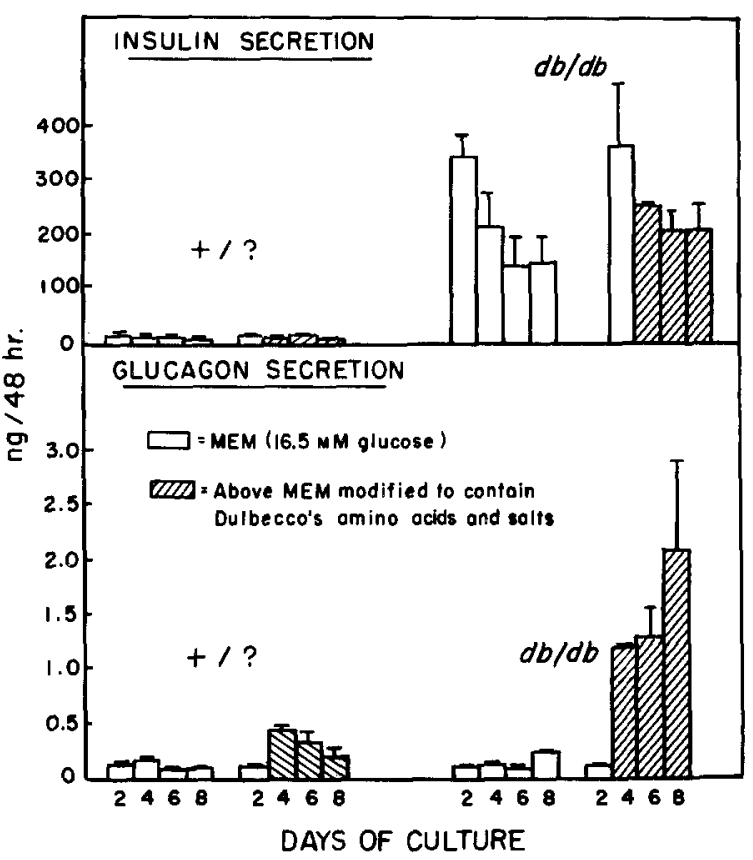

Fig. 3. Insulin and glucagon release in response to elevated medium amino acids. Each value represents mean \pm SEM for data collected in two experiments

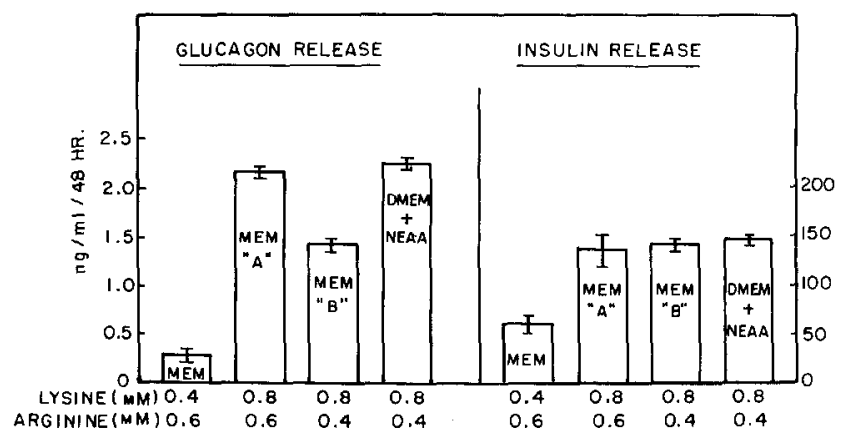

Fig. 4. Effects of basic amino acids on insulin and glucagon release over the day 8 to 10 culture interval. Values represent mean \pm SD for 2 replications in paired Lab-Tek chambers. Medium glucose concentration $5.5 \mathrm{mmol} / 1$

Further evaluation of the aminogenic stimulus to mutant A-cell activity revealed that addition of basic amino acids, particularly lysine, to MEM resulted in enhanced glucagon secretion. Elevation from MEM to DMEM levels of other amino acids (aromatic, acidic, neutral, and branched chain) did not trigger glucagon hypersecretion. Elevation of medium lysine from $0.4 \mathrm{mmol} / 1$ (MEM level) to $0.8 \mathrm{mmol} / 1$ found in DMEM (MEM " $A$ ") resulted in glucagon release equal to that produced by DMEM plus non-essential amino acids (DMEM + NEAA, Fig. 4). Arginine, 
Table 4. Medium effect on ${ }^{3} \mathbf{H}$-tryptophan incorporation by 14 day $d b^{3 \mathrm{~J}} / d b^{3 \mathrm{~J}}$ islet cell monolayer cultures

\begin{tabular}{llll}
\hline & $\begin{array}{l}\text { Total c.p.m. in column peak } \\
\text { Medium }\end{array}$ & $\begin{array}{l}\text { Glucagon } \\
\text { void volume } \\
\text { (fraction 10) } \\
\text { radio- } \\
\text { activity }^{\mathrm{a}}\end{array}$ \\
\hline MEM & 27578 & $\begin{array}{l}\text { native glucagon } \\
\text { (peak fraction 23) }\end{array}$ & 10.0 \\
DMEM & 42575 & 7932 & 29.1 \\
\hline
\end{tabular}

Paired cultures were labelled for $8 \mathrm{~h}$ in either MEM or DMEM containing $1.75 \mathrm{mmol} / 1$ glucose. Cultures were then incubated in two successive $8 \mathrm{~h}$ chases of the same medium without radioisotope. Cell extracts made at $24 \mathrm{~h}$ were analyzed on Biogel $\mathrm{P}-10$ columns as described in text

a c.p.m./pg glucagon in fraction 23

another basic amino acid known to stimulate glucagon release, may also influence function of mutant A-cells in culture, since lowering it from $0.6 \mathrm{mmol} / \mathrm{l}$ (MEM level) to $0.4 \mathrm{mmol} / 1$ (DMEM level) caused a somewhat diminished glucagon secretion (MEM "B").

Hypersecretion of glucagon in response to DMEM levels of amino acids was not altered by changes in medium glucose concentration, whereas B-cell responsiveness to aminogenic stimulation was enhanced at lower glucose concentration. Thus, while $d b^{3 \mathrm{~J}} / d b^{3 \mathrm{~J}}$ B-cells exhibited a much reduced insulin secretion when tested in $5.5 \mathrm{mmol} / 1$ glucose-containing medium (Fig. 4) instead of $16.5 \mathrm{mmol} / 1$ (Fig. 3), a 3 -fold potentiation of release was achieved by doubling the lysine component to a DMEM level (MEM "A", Fig. 4).

\section{Glucagon Biosynthesis}

Mutant cells labelled with ${ }^{3} \mathrm{H}$-tryptophan on days 7 , 14, and 21 of culture and processed for Biogel P-10 chromatography showed active incorporation of radioisotope into fractions with glucagon-like activity. Under low-glucose and serum-free labelling conditions, there was very little ${ }^{14} \mathrm{C}$-isoleucine incorporation into precursor or native insulin activities in Bcell enriched $d b^{3 \mathrm{~J}} / d b^{3 \mathrm{~J}}$ cultures (not shown). Few $+/$ ? cultures contained many surviving islet cells by day 14 of culture, so that compared to the robust $d b^{3 \mathrm{~J}} / d b^{3 \mathrm{~J}}$ preparations, little incorporation of ${ }^{3} \mathrm{H}$-tryptophan into glucagon-like species was generally observed above background levels.

Enhanced incorporation of ${ }^{3} \mathrm{H}$-tryptophan into glucagon-likecomponents in $d b^{3 \mathrm{~J}} / d b^{3 \mathrm{~J}}$ long-term cultures was dependent upon medium composition (Table 4). It can be seen that the void volume peaks of cultures labelled in MEM versus DMEM showed less than a 2-fold difference in radioactivity following a $16 \mathrm{~h}$ chase. Total and specific radioactivity eluting in the native glucagon peak ( 3,500 daltons) were 4and 3-fold elevated, respectively, after labelling in DMEM as compared to MEM. Thus, DMEM stimulation of glucagon release in $d b^{3 \mathrm{~J}} / d b^{3 \mathrm{~J}}$ cultures could be correlated with an apparent increase in biosynthesis. Although data are not presented here, analysis of Biogel $\mathrm{P}-10$ fractionated extracts revealed ${ }^{3} \mathrm{H}$ labelled fractions with glucagon-like immunoreactivity widely distributed between the void volume (MW $\supseteq 20,000$ daltons) and the native glucagon peak elution volume (fraction 23). In pulse-chase experiments, a distinct time-dependent shift of higher-to-lower molecular weight ${ }^{3} \mathrm{H}$-labelled species with glucagon activity could be shown over a $48 \mathrm{~h}$ period. However, the structural relationship between these higher molecular weight fractions (putative proglucagons) and native glucagon have not yet been analyzed.

\section{Discussion}

The crucial role of culture media composition in maintaining viability and differentiated expression by mouse B-cells has been amply documented [11-18]. Mouse islet cells apparently differ from those of the rat by not showing an absolute requirement for serum in the culture medium. Thus, viability, glucose-sensitive insulin release, and (pro)insulin biosynthesis can all be maintained when bovine serum albumin (BSA) is substituted for calf or fetal calf serum, and provided that elevated medium glucose concentrations are maintained $[12,19]$. Serum is required for mouse islet cell attachment to occur [18]. Once cells have attached, deletion of serum offers several important advantages. Under our conditions, serum removal accelerated islet cell flattening and spreading on both glass and plastic substrata. Non-islet cell types such as fibroblasts, duct cells, and exocrine cells that are maintained for variable periods in serum-containing media were lost within a week of serum-free culture [6]. In addition to elimination of unwanted non-islet cell types, serum-free conditions avoid the complications of uncontrolled effects produced by the wide variety of hormones present in serum at highly variable levels [20]. Further, degradation of islet hormones in cell-free culture medium, as assessed by loss of immunoreactivity of tracer quantitites of radioactive insulin and glucagon, was much reduced when BSA is substituted for serum [6]. The only reported disadvantage of mouse islet culture in serum-free media is that 
B-cell function, while still maintained, was not as active as in serum-containing media [12]. No data for maintenance of optimal A-cell function under different culture conditions have yet been reported.

In the present study, two closely-related and relatively simple tissue culture media have proven useful in elucidating a genotype-mediated difference in Acell responsiveness to physiological levels of amino acids. Levels of mean glucagon secretion over an 8 day period by $+/$ ? versus $d b^{3 \mathrm{~J}} / d b^{3 \mathrm{~J}}$ A-cells cultured in MEM (Table 1 and Fig. 3) were almost identical. These data, coupled with immunocytochemical staining of A-cells, suggest that our system of establishing cultures from dissociated islet cells from equal numbers of $+/$ ? versus $d b^{3 \mathrm{~J}} / d b^{3 \mathrm{~J}}$ pancreases roughly achieved equivalance of $\mathrm{A}$-cell numbers in each type of culture. Transfer to DMEM of cultures previously secreting equivalent levels of glucagon in MEM allowed discrimination between genotypes, namely a strong medium/genotype/days interaction (Table 1 and Fig. 3). Our data (Figs. 3 and 4) show that the basis of the genotype/medium effect was heightened responsiveness of $d b^{3 \mathrm{~J}} / d b^{3 \mathrm{~J}} \mathrm{~A}$-cells to elevated levels of amino acids, and specifically 1-lysine, in DMEM. The finding that DMEM stimulated glucagon biosynthesis as well as secretion presumably accounts for increasing glucagon release with time without any apparent ultrastructural evidence of $d b^{3 \mathrm{~J}} / d b^{3 \mathrm{~J}}$ A-cell degranulation.

In sharp contrast to the equivalent glucagon secretion in MEM by both genotype classes was the gross difference in insulin levels. The elevated insulin levels in $d b^{3 \mathrm{~J}} / d b^{3 \mathrm{~J}}$ cultures in both MEM and DMEM was a reflection in vitro of the increased numbers of B-cells in the hyperplastic islets observed in situ [5]. We consider it unlikely that the hypersensitivity in vitro of $d b^{3 \mathrm{~J}} / d b^{3 \mathrm{~J}}$ A-cells is a simple artifact of the elevated insulin levels insofar as addition of $300 \mathrm{ng} / \mathrm{ml}$ of bovine-porcine insulin to $+/$ ? cultures for 8 days produced no change in endogenous glucagon secretion or in viability of the cultures (data not presented). Our evidence, then, indicates that the sustained glucagon secretion over time by $d b^{3 \mathrm{~J}} / d b^{3 \mathrm{~J}} \mathrm{~A}-$ cells in DMEM reflects stimulation of proglucagon/ glucagon biosynthesis whereas the lower and transient stimulation in genotype controls reflects its lack. We cannot, however, rule out the possibility that the robustness of mutant cultures after 14 days of culture in either MEM or DMEM was in part conditioned by the higher than control medium insulin levels.

We have found the 2-fold elevated lysine level in DMEM to be very close to saturation for stimulation of glucagon secretion by cultured $d b^{3 \mathrm{~J}} / d b^{3 \mathrm{~J}}$ A-cells. Our finding that these cells responded to elevations in medium lysine and arginine but not to aromatic, neutral, acidic, or branched-chain amino acids is consistent with the results of McChesney et al. [21] who found glucagon release by isolated mouse islets responsive to $1 \mathrm{mmol} / 1$ concentrations of arginine and lysine but not to histidine or leucine. Further, the observation that glucagon release was more than doubled by treatment with $10 \mu \mathrm{mol} / \mathrm{l}$ ouabain suggested that glucagon release was partially dependent on the intracellular ionic gradient [21]. Evidence suggesting altered cell surface activity in $d b / d b$ islets is provided by reports of continuous depolarization [22] and a triiodothyronine-insensitive $\mathrm{Na}^{+}-\mathrm{K}^{+}$ ATPase activity [23]. We do not know whether glucagon hypersecretion by mutant A-cells in response to elevations of medium lysine is due to a signal generated by binding of the amino acid to a cationic transport system at the cell surface as suggested for mouse islets [24], or to a signal generated by metabolism of lysine, or to a direct and specific effect of the amino acid on glucagon biosynthesis.

In the companion study of the $d b^{3 \top}$ mutation in vivo, increasing levels of palsma glucagon in the face of declining plasma insulin levels in aging mutants was assumed to be evidence of A-cell hypersecretory function [5]. The finding reported here of increased sensitivity to aminogenic stimulation by cultured $d b^{3 \mathrm{~J}} / d b^{3 \mathrm{~J}}$ A-cells (derived from aged mutant mice) not only is consistent with the above-mentioned study, but also would support previous reports of increased A-cell sensitivity to arginine in diabetic $(d b / d b)$ and obese $(o b / o b)$ mice both in vivo $[4,25]$ and in vitro $[3,26]$. The discovery that A-cell hypersecretion of glucagon preceded B-cell hypersecretion of insulin in pancreatic cell cultures established from pre-hyperglycaemic BL/Ks $m d b / m d b$ (misty diabetic) 4 day old mice [2] suggests that Acell hypersensitivity may be an early and persistent expression of the $d b$ mutation in islet cells.

Acknowledgements. The technical assistance of Sue Cook, Christine Karcher, Robert Ruether, and Lester Bunker is gratefully acknowledged. This research was supported by NIH grants AM 17631, AM 19825, and a grant from the Juvenile Diabetes Foundation and the American Diabetes Association.

\section{References}

1. Coleman DL, Hummel KP (1974) Hyperinsulinemia in preweaning diabetes $(d b)$ mice. Diabetologia 10:607-610

2. Leiter EH, Coleman DL, Eppig JJ (1979) Endocrine pancreatic cells of postnatal $(d b)$ mice in cell culture. In Vitro 15: $507-521$

3. Laube H, Fussganger RD, Maier V, Pfeiffer EF (1973) Hyperglucagonemia of the isolated perfused pancreas of diabetic mice $(d b / d b)$. Diabetologia 9: 400-402

4. Stearns SB, Bezo CA (1978) Glucagon and insulin relationships in genetically $(d b / d b)$ and in streptozotocin-induced diabetic mice. Horm Metab Res 10: 20-23 
5. Leiter EH, Coleman DL, Eisenstein AB, Strack I (1980) A new mutation $\left(d b^{3 J}\right)$ at the diabetes locus in strain $129 / \mathrm{J}$ mice. I. Physiological and histological characterization. Diabetologia 19: 58-65

6. Leiter EH, Bedigian HG (1979) Intracisternal A-particles in genetically diabetic mice: Identification in pancreas and induction in cultured B-cells. Diabetologia 17: 175-185

7. Kedinger M, Moody A, Launay JF, Haffen K (1977) Establishment of serum based medium essentially free of proteolytic activity for the culture of mouse pancreatic islets. Experientia 33: 972-973

8. Lernmark A, Sehlin J, Täljedal I-B, Kroma H, Nerup J (1978) Possible toxic effects of normal and diabetic patient serum on pancreatic B-cells. Diabetologia 14: 25-31

9. Eagle $H$ (1959) Amino acid metabolism in mammalian cell cultures. Science 130: 432-437

10. Winer BJ (1971) Statistical principles in experimental design, 2nd ed. McGraw-Hill, New York, p 347-349

11. Andersson A (1976) Tissue culture of isolated pancreatic islets. Acta Endocrinol [Suppl] (Khb) 205: 283-293

12. Andersson A (1978) Isolated mouse pancreatic islets in culture: Effects of serum and different culture media on the insulin production of the islets. Diabetologia 14: 397-404

13. Segerström K, Andersson A, Lundquist G, Petersson B, Hellerström C (1976) Regulation of the glucagon release from mouse pancreatic islets maintained in tissue culture at widely different glucose concentrations. Diabete Metab 2: 45-48

14. Andersson A (1974) Long-term effects of glucose on insulin release and glucose oxidation by mouse pancreatic islets maintained in tissue culture. Biochem J 140: 377-382

15. Andersson A, Westman I, Hellerström C (1974) Effects of glucose on the ultrastructure and insulin biosynthesis of isolated mouse pancreatic islets maintained in tissue culture. Diabetologia 10: 743-753

16. DeGasparo M, Milner GR, Norris PD, Milner RDG (1978) Effect of glucose and amino acids on foetal rat pancreatic growth and insulin secretion in vitro. $J$ Endocrinol 77: $241-248$
17. Leach FN, Ashworth MA, Barson AJ, Milner RDG (1973) Insulin release from human foetal pancreas in tissue culture. $J$ Endocrinol 59: 65-79

18. Leiter EH, Coleman DL, Waymouth C (1973) Cell culture of the endocrine pancreas of the mouse in chemically-defined media. In Vitro 9: 421-433

19. Buitrago A, Gylfe E, Hellman B, Idahl L- $\AA$, Johansson M (1975) Function of microdissected islets cultured in a chemically-defined medium. I. Insulin content and release. Diabetologia 11: 535-540

20. Honn KV, Singley JA, Chavin W (1975) Fetal bovine serum: A multivariate standard. Proc Soc Exp Biol Med 149: 344-347

21. McChesney T, Schofield JG (1969) Studies on the secretion of pancreatic glucagon. Diabetes 18: 627-632

22. Meissner HP, Schmidt $H$ (1976) The electrical activity of pancreatic $\beta$-cells of diabetic mice. FEBS Lett $67: 371-374$

23. Bray GA, York DA, Yukimura Y (1978) Activity of $\left(\mathrm{Na}^{+}-\right.$ $\mathrm{K}^{+}$)-ATPase in the liver of animals with experimental obesity. Life Sci 22: 1637-1642

24. Christiansen H, Hellman B, Lernmark A, Sehlin J, Tager H, Täljedal I-B (1971) In vitro stimulation of insulin release by non-metabolizable transport-specific amino acids. Biochim Biophys Acta 241: 341-348

25. Dubuc PU, Mobley PW, Mahier RJ, Ensinck JW (1977) Immunoreactive glucagon levels in obese-hyperglycemic $(\mathrm{ob}$ / ob) mice. Diabetes 26: 841-846

26. Laube H, Fussganger RD, Pfeiffer EF (1974) Paradoxical glucagon release in obese-hyperglycemic mice. Horm Metab Res 6: 426

Received: March 26, 1979 ,

and in revised form: March 3, 1980

Dr. E. H. Leiter

The Jackson Laboratory

Bar Harbor, ME 04609

USA 